\title{
Permeability of Granite Including Macro-Fracture Naturally Filled with Fine-Grained Minerals
}

\section{$\operatorname{AUTHOR}(\mathrm{S})$ :}

Nara, Yoshitaka; Kato, Masaji; Niri, Ryuhei; Kohno, Masanori; Sato, Toshinori; Fukuda, Daisuke; Sato, Tsutomu; Takahashi, Manabu

\section{CITATION:}

Nara, Yoshitaka ...[et al]. Permeability of Granite Including Macro-Fracture Naturally Filled with Fine-Grained Minerals. Pure and Applied Geophysics 2018, 175(3): 917-927

\section{ISSUE DATE:}

2018-03

URL:

http://hdl.handle.net/2433/230347

\section{RIGHT:}

This is a post-peer-review, pre-copyedit version of an article published in 'Pure and Applied Geophysics'. The final authenticated version is available online at: http://dx.doi.org/10.1007/s00024-017-1704-x.; The full-text file will be made open to the public on 01 March 2019 in accordance with publisher's 'Terms and Conditions for Self-Archiving'.; この論文 は出版社版でありません。引用の際には出版社版をご磼認ご利用ください。; This is not the published version. Please cite only the published version. 
1 Permeability of granite including macro-fracture naturally filled with fine-grained

2 minerals

3

4 Yoshitaka Nara ${ }^{1}$, Masaji Kato ${ }^{2}$, Ryuhei Niri $^{3}$, Masanori Kohno ${ }^{4}$, Toshinori Sato ${ }^{5}$,

$5 \quad$ Daisuke Fukuda ${ }^{2}$, Tsutomu Sato ${ }^{2}$, Manabu Takahashi $^{6}$

6

7 1. Department of Civil and Earth Resources Engineering, Graduate School of

8 Engineering, Kyoto University, Kyoto Daigaku Katsura, Nishikyo-ku, Kyoto 615-8540,

9 Japan.

10

2. Faculty of Engineering, Hokkaido University, Kita 13 Nishi 8, Kita-ku, Sapporo,

Hokkaido 060-8628, Japan.

3. Department of Civil Engineering, Faculty of Engineering, Tottori University, 4-101

Koyama-Minami, Tottori 680-8552, Japan.

18 School of Engineering, Tottori University, 4-101 Koyama-Minami, Tottori 680-8552,

19 Japan.

20

5. Japan Atomic Energy Agency, 432-2 Hokushin, Horonobe-cho, Hokkaido 098-3224, Japan.

6. National Institute of Advanced Industrial Sciences and Technology, 1-1-1 Higashi, 


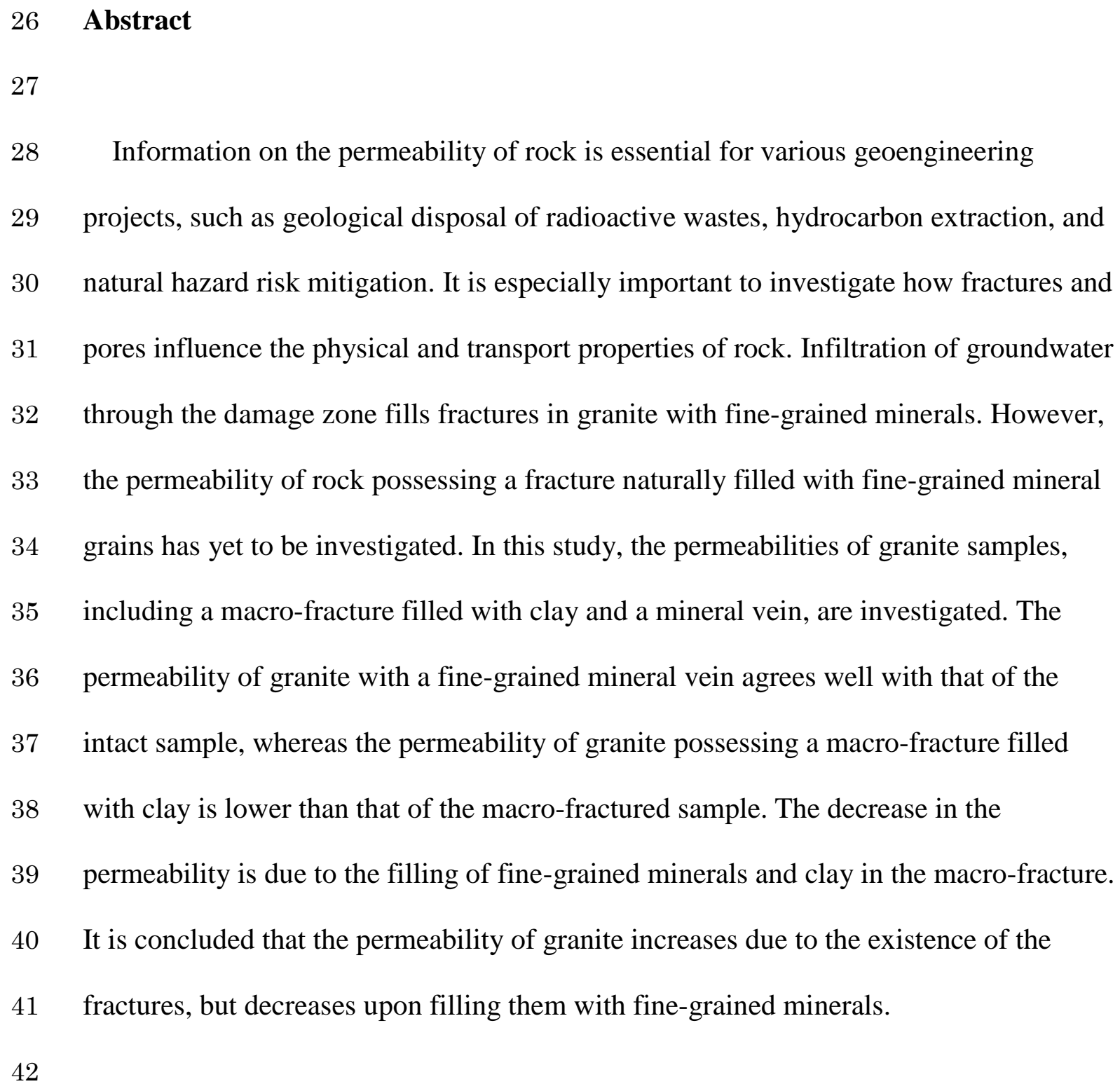
with clay is lower than that of the macro-fractured sample. The decrease in the permeability is due to the filling of fine-grained minerals and clay in the macro-fracture.

40 It is concluded that the permeability of granite increases due to the existence of the

41 fractures, but decreases upon filling them with fine-grained minerals.

43 Keywords: Permeability, Granite, Fracture, Clay, Mineral vein 


\section{Introduction}

It is essential to investigate the permeability of rock and the influence of the fractures on various engineering projects and natural hazard risk mitigation. For geological disposal of radioactive wastes, the intensity of radioactivity of radionuclides should be reduced by both engineered barriers (e.g., a bentonite buffer) and natural barriers (e.g., a rock mass.) If a radioactive waste repository is located in an area where the hydraulic gradient and the permeability are high, the retardation of migration of radionuclides by these barriers may not be sufficient. The existence of fractures can be undesirable for geological disposal of radioactive wastes, because the higher density and connectivity of fractures increase the permeability (Gueguen and Dienes, 1989). In addition, fractures in rocks play an important role in the fluid flow and distribution of the pore pressure.

Consequently, fractures greatly influence volcanic eruptions. On the other hand, fractures are essential to boost the flow of hydrocarbons (natural gas and oil) in a rock mass for oil and natural gas extraction.

Fractures and pores are ubiquitous on all scales in crustal rocks. In the upper crust, fractures and pores remarkably influence the physical and transport properties of rocks. The existence of fractures and pores makes rock more compliant (Brace, 1965; Walsh, 1965; Hazzard et al., 2000; Abe, 2016; Griffiths et al., 2017), weaker (Nara and Kaneko, 2006; Fujii et al., 2007; Nasseri et al., 2005, 2007; Nara, 2015), and more permeable if they are connected together in a percolating network (Gueguen and Dienes, 1989; Gueguen et al., 1997; Sausse et al., 2001; Benson et al., 2006a; Chaki et al., 2008; Nasseri et al., 2009; Nara et al., 2011a).

It is well known that the aperture of the fracture significantly affects the permeability of rock (Norton and Knapp, 1977; Witherspoon et al., 1980; Walsh, 1981; David, 1993; 
69 Unger and Mase, 1993; Amadei and Illangasekare, 1994; Oron and Berkowitz, 1998;

70 Suzuki et al., 1998). Nara et al. (2011a) reported that the introduction of open macro-

fractures and micro-fractures increase the permeability of basalt when the initial permeability is low. The permeability decreases as the confining pressure increases due to the closure of fractures in basalt (Vinciguerra et al., 2005; Fortin et al., 2011; Nara et al., 2011a) and granite (Pratt et al., 1977; Kranz et al., 1979; Darot et al., 1992; Morrow and Lockner, 1997; Benson et al., 2006b). Wang et al. (2016) reported that the permeability of fractured rock decreases if the macro-fracture is filled with fine-grained particles. In addition, they showed that the permeability depends on the grain size of the particles filling the macro-fracture; the permeability decreases as the grain size 79 decreases.

80 The fractures in rock are often filled naturally with fine-grained mineral grains (i.e., clay). According to Ishibashi et al. (2016), fractures in granite are filled with clay due to the infiltration of groundwater through the damage zone. Clay may alter the permeability, decreasing the fracture aperture. However, the permeability of rock containing a macro-fracture naturally filled with fine-grained mineral grains has yet to

85 be investigated.

86 In this study, we examine the permeability of crystalline rock including a macro-

87 fracture, a mineral vein, and a macro-fracture filled with fine-grained mineral grains

88 such as clay. Specifically, we investigate whether the permeability of the macro-

89 fractured rock can be recovered by sealing and healing the macro-fracture upon filling with fine-grained minerals. 
92

\section{Rock sample}

The rock sample is Toki granite, which was obtained in the Mizunami Underground

Research Laboratory. This material has widely been used in previous research (e.g.,

Schubnel et al., 2003; Lanaro et al., 2009; Nara et al., 2011b, c; Sanada et al., 2013;

Yamamoto et al., 2013; Yamasaki et al., 2013; Hashiba and Fukui, 2016). Specifically,

we used the rock core samples obtained from a 200-m depth in the Mizunami

Underground Research Laboratory in Mizunami-City, Japan (Iwatsuki et al., 2005; Nara et al., 2011b; Yuguchi et al., 2012; Koike et al., 2015). The cores often include natural macro-fractures. Such macro-fractures are commonly filled with clay and fine-grained minerals, which are solidified and become a mineral vein. Figure 1 shows photos of the rock core samples of Toki granite. Figures $1 \mathrm{a}, \mathrm{b}$, and c show the core samples containing macro-fractures, a mineral vein, and clay fillings naturally included in rock, respectively.

In this study, we prepared four types of samples: an intact specimen (TG-i), a macrofractured specimen without filling (TG-f), a specimen including a mineral vein (TG-v), and a specimen with a macro-fracture naturally filled by clay (TG-c). From these samples, we prepared cylindrical specimens with 50-mm diameters and 25-mm lengths for the permeability tests (Figure 2). Figure 3 shows photomicrographs of TG-i (Fig. 3a), TG-v (Fig. 3b), and TG-c (Fig. 3c) taken from thin sections (0.03-mm thick) under crossed nicols. The mineral grains in the vein in TG-v in Fig. 3b are mainly solidified strongly fine-grained feldspars (plagioclase and potash feldspar) and mica. The clay included in TG-c (Fig. 3c) consists mainly of illite and a small amount of carbonate minerals. 


\section{Methodology}

116

\subsection{Experimental Method}

Before the permeability tests, TG-i and TG-f were saturated with distilled water.

Since TG-c can be fractured along the clay layer due to the weakening of illite by water

121 (Francisca et al., 2005; Nara et al., 2011d, 2012), this specimen was saturated with a 1-

122 M sodium chloride solution. Previous research demonstrated that crack propagation in

123 rock containing clay is depressed in 1-M sodium chloride solution (Nara et al., 2014).

Similarly, TG-v was saturated in a 1-M sodium chloride solution.

125 To evaluate the permeability, we used the transient pulse method for TG-i, TG-v, and

TG-c because this method is useful for samples with a low permeability (Brace et al.,

1968; Hsieh et al., 1981; Zhang et al., 2000a). A hydraulic head pulse (the pore pressure pulse) was applied on the upstream side of the specimen. Then the difference between the upstream and downstream pore pressure decreased with elapsed time. The permeability was determined from this temporal decrease of pore pressure difference in 131 the specimen.

132 Brace et al. (1968) introduced the following equation to evaluate the permeability by the transient pulse method:

$$
\frac{\Delta h(t)}{H}=\frac{h_{u}(t)-h_{d}(t)}{H}=\exp \left\{-\frac{K A t}{l}\left(\frac{1}{S_{u}}+\frac{1}{S_{d}}\right)\right\}
$$

where $t$ is the time, $\Delta h(t)$ is the upstream and downstream difference of the hydraulic head, $h_{u}(t)$ is the hydraulic head at the upstream, $h_{d}(t)$ is the hydraulic head at the downstream, $H$ is the difference of the hydraulic head at $t=0, K$ is the permeability, $A$ is the cross-sectional area of the specimen, $l$ is the length of the specimen, $S_{u}$ is the 
compressional storage of the upstream reservoir, and $S_{d}$ is the compressional storage of

140 the upstream reservoir. Following the methodology of Zhang et al. (2000b), both $S_{u}$ and

$141 S_{d}$ were set to $8.0 \times 10^{-10} \mathrm{~m}^{2}$.

142 Because the permeability could be high for TG-f due to the existence of a macro-

143 fracture, the permeability measurement of TG-f was conducted by the constant flow

144 method (formerly named as flow pump method) (Olsen, 1966; Morin and Olsen, 1987;

145 Esaki et al., 1996). The permeability of a material is determined by Darcy's law using

146 the pressure difference induced by the imposed steady state constant flow rate. For the

147 constant flow method, the permeability is evaluated using the following equation

148 (Olsen, 1966):

$$
K=\frac{Q l}{A(h u-h d)}
$$

where $Q$ is the flow rate.

\subsection{Experimental Apparatus}

Figure 4 illustrates the permeability measurement system used in this study. This system can be used to conduct various methods of permeability test. Here we used the constant flow method and the transient pulse method. The permeability measurement system mainly consists of the pressure vessel, the confining fluid controller, the pore fluid controller, the data logger, and the temperature controllers.

This system was placed in a temperature-controlled room. It was possible to reduce the temperature change during the measurement rigorously. All the measurements were acquired at a constant temperature of $22 \pm 0.1^{\circ} \mathrm{C}$.

The values of the pressure difference between the upstream and the downstream pore 
163 pressures is obtained from the differential pressure transduces. The accuracy was 0.35

$164 \mathrm{kPa}$. The pore pressure was around $1 \mathrm{MPa}$ for all measurements. Pressure to the rock

165 specimens was applied using a syringe pump. For the transient pulse method, the

166 applied pore pressure pulse was around $40 \mathrm{kPa}$ (4\% of the pore pressure). For the

167 constant flow method, the flow rates were $0.5 \mathrm{ml} / \mathrm{s}, 0.25 \mathrm{ml} / \mathrm{s}, 0.15 \mathrm{ml} / \mathrm{s}, 0.10 \mathrm{ml} / \mathrm{s}$, and

$1680.05 \mathrm{ml} / \mathrm{s}$ under effective confining pressures at 1-3 MPa, 3-4 MPa, 4-5 MPa, 5-7 MPa,

169 and 7-9 MPa, respectively. These values were selected to create an equal upstream and

170 downstream pore pressure difference for all measurements, because it is important to

171 control the pore pressure difference between upstream and downstream to ensure the

172 constant flow rate in the specimens.

173 The confining pressure was applied using the double plunger pump. The maximum

174 pressure of the pressure vessel was $10 \mathrm{MPa}$. Measurements were acquired under

175 confining pressures between 2 to $10 \mathrm{MPa}$. Consequently, the effective pressures ranged

176 from 1 to $9 \mathrm{MPa}$. 
177

178

179

180

181

182

183

184

185

186

187

188

189

190

191

192

193

194

195

196

197

198

199

200

\section{Results}

It was necessary to apply a small pressure pulse on the upstream side of the specimen during the transient pulse measurements to induce laminar flow in the specimen (Brace et al., 1968). Figure 5 shows the temporal changes of the upstream and downstream hydraulic pressure difference for TG-i (Fig. 5a), TG-v (Fig. 5b), and TG-c (Fig. 5c) at a 2-MPa confining pressure. In all cases, the hydraulic pressure difference decreased exponentially. We evaluated the permeability by applying Eq. (1) to the data shown in Fig. 5.

For TG-f, we used the constant flow method. Figure 6 shows an example of the temporal change of the upstream and downstream hydraulic pressure difference in TG-f under a confining pressure of $2 \mathrm{MPa}$, in which the flow rate was $0.5 \mathrm{ml} / \mathrm{s}$. The average value between 150 to $250 \mathrm{~s}(18.5 \mathrm{kPa})$ was used to evaluate the permeability.

Figure 7 and Table 1 show the relationship between the permeability and the effective pressure. The permeability of TG-f was much higher than that of other specimens, and decreased remarkably as the effective pressure (confining pressure) increased. The permeability of TG-f decreased by more than one order of magnitude when the effective pressure increased from $1 \mathrm{MPa}$ to $9 \mathrm{MPa}$. The permeability of TG-v agreed well with that of TG-i at all effective pressures. In addition, the values of the permeability of TG-i and TG-v were independent of the effective pressure. The permeability of TG-c was much lower than that of TG-f, but slightly higher than those of TG-i and TG-v. Moreover, the permeability of TG-c decreased as the effective pressure increased. The permeability of TG-c decreased by around one order of magnitude when the effective pressure increased from $1 \mathrm{MPa}$ to $9 \mathrm{MPa}$. 


\section{1 \\ 5. Discussion}

202

203

5.1 Permeability of intact and macro-fractured granite

204

205

The permeability of macro-fractured granite (TG-f) is much higher than that of intact

granite (TG-i) (Fig. 7 and Table 1). In the pressure range of this study, it is 3-4 orders of

207 magnitude higher, demonstrating that the introduction of a macro-fracture in granite

208 increases the permeability significantly.

209 The difference of the permeability between TG-f and TG-i decreases as the effective

210 pressure increases. This may be due to the remarkable decrease in the permeability of

211 TG-f with increasing pressure. Nara et al. (2011) suggested that the closure of a macro-

212 fracture under hydrostatic pressure decreases the permeability of macro-fractured low-

213 porosity rock (Seljadalur basalt) even when the applied pressure is low. The

214 permeability decrease for TG-f is attributed to the closure of the macro-fracture under

215 hydrostatic pressure.

216 In contrast, the permeability of TG-i remains almost constant over the entire pressure

217 range. Nara et al. (2011) reported that the closure of micro-fractures can decrease the

218 permeability of intact low-porosity rock (Seljadalur basalt) if a high hydrostatic pressure

219 is applied on the rock. In particular, Nara et al. (2011) indicated that the closure of the

220 micro-fracture predominantly affects the decrease in the permeability of Seljadalur

221 basalt when the hydrostatic pressure exceeds $20 \mathrm{MPa}$, which is higher than the pressure

222 in this study. Thus, the change in permeability for the intact granite is negligible in this

223 study due to the low applied pressure. 
5.2 Permeability of granite including a mineral vein and macro-fracture with clays

Because the permeability of TG-v agrees well with that of the intact specimen (TG-i), the original macro-fracture in granite is almost completely filled with fine-grained minerals. In addition, the change of the permeability for TG-v is small, which is the same tendency with TG-i. It is considered that the applied pressure in this study has a negligible influence on the closure of fractures in TG-v as well as TG-i.

The macro-fracture in TG-c is partly filled with clay because the permeability of TG$\mathrm{c}$ is higher than that of the intact specimen (TG-i). The permeability of TG-c decreases as the effective pressure increases (Fig. 7). The closure of the macro-fracture under hydrostatic pressure induces the decrease in the permeability of TG-c.

The permeability of TG-c is much lower than that of TG-f. This is attributed to clay filling the macro-fracture. The decrease in the aperture occurs in the fracture in TG-c, decreasing the permeability.

According to Nara et al. (2011a), if three macro-fractures with almost same size are included in a low-porosity rock (Seljadalur basalt), the permeability is around one order of magnitude higher than that of the same rock with one macro-fracture. The position of the macro-fracture naturally filled with clay in TG-c is not the central part of the specimen (Fig. 2d). If the area of the macro-fracture is located in the central part of the specimen and the size of the macro-fracture doubles, the permeability may also increase. Because the size difference in this case is smaller than that of Nara et al. (2011), the increase of the permeability should be less than one order even if the macrofracture is located the central part in TG-c. Therefore, the location of the macro-fracture in TG-c has a negligible influence on the permeability. 
251

252

253

$$
Q=-K A \frac{d h}{d x}
$$

266 where $A$ is the cross-sectional area of the specimen and is equal to $\pi D^{2} / 4$. Then the

$$
\frac{a^{3} \rho g D}{12 \mu}=K A
$$

269 Consequently,

$$
a=\sqrt[3]{\frac{3 \pi \mu D K}{\rho g}}
$$

271 Using this equation, the hydraulic aperture $a$ can be evaluated. 
272 The evaluated hydraulic apertures for all specimens are shown at elevated effective

273 confining pressures (Fig. 8). TG-f has the largest hydraulic aperture. The hydraulic

274 aperture decreases with increasing the pressure for TG-f and TG-c, whereas TG-i and

275 TG-v have a negligible dependence on the hydraulic aperture. The hydraulic aperture of

276 TG-c is around one order of magnitude greater than the intact specimen. It is considered

277 that almost $90 \%$ of the aperture of the macro-fracture in TG-c is filled with fine-grained 278 clay.

279 Generally the existence of fractures and their network are undesirable for the

280 geological disposal of radioactive wastes. According to Heap et al (2014), stylolites in

281 the Jurassic limestone at Bule (France) are not barriers to fluid flow. However, in the

282 case of granite, the permeability decreases as the aperture decreases for fractures

283 naturally closed by clay, suggesting that the existence of fractures in granitic rocks is

284 not problematic when considering the long-term use of an underground granite rock 285 mass. 


\section{6. Conclusions}

287

288 The permeability of Toki granite, including a macro-fracture filled with clay or a

289 mineral vein, is investigated and compared with the permeability of intact and macro-

290 fractured granite samples. The permeability of the macro-fractured granite is much

291 higher than that of intact sample, and decreases as the effective confining pressure

292 increases. The permeability of the sample with a fine-grained mineral vein agrees well

293 with that of the intact sample, whereas the permeability of granite with a macro-fracture

294 filled with clay is less than that of the macro-fractured granite.

295 The permeability of fractured granite decreases by filling with clay. The evaluation of

296 the hydraulic aperture suggests that the permeability decreases upon filling the macro-

297 fracture with fine-grained minerals and clay. Additionally, the presence of fractures

298 increases the permeability of granite, but filling the features with fine-grained minerals

299 decreases the permeability, which can be helpful for the geological disposal of

300 radioactive wastes. 


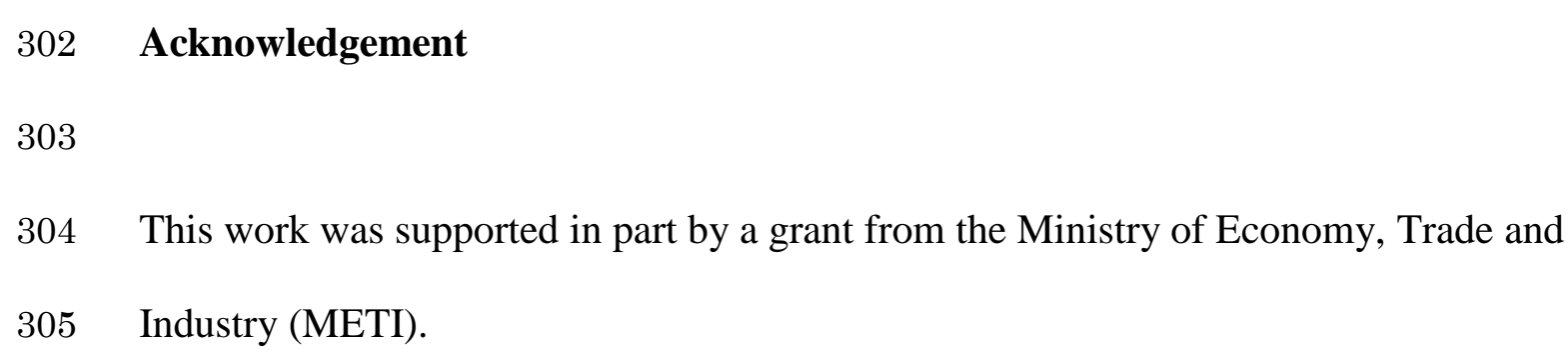




\section{References}

307

308

Abe, S., 2016. Comparison of discrete element simulations to theoretical predictions of the elastic moduli of damaged rocks. Int. J. Rock Mech. Min. Sci. 88, 265-272.

Amadei, B., Illangasekare, T., 1994. A mathematical model for flow and solute transport in non-homogeneous rock fractures. Int. J. Rock Mech. Min. Sci. \& Geomech. Abstr. 31, 719-731.

Bear, J. Dynamics of fluids in porous media. New York: Dover Publications; 1988.

Benson, P.M., Meredith, P.G., Schubnel, A., 2006a. Role of void space geometry in permeability evolution in crustal rocks at elevated pressure. J. Geophys. Res. 111, B12203, doi: 10.1029/2006JB004309.

Benson, P., Schubnel, A., Vinciguerra, S., Trovato, C., Meredith, P., Young, R. P., 2006 b. Modeling the permeability evolution of microcracked rocks from elastic wave velocity inversion at elevated isotropic pressure. J. Geophys. Res. 111, B04202, doi: $10.1029 / 2005 J B 003710$.

Brace, W.F., 1965. Some new measurements of linear compressibility of rocks. J. Geophys. Res. 70, 391-398.

Brace, W.F., Walsh, J.B., Frangos, W.T., 1968. Permeability of granite under high pressure. J. Geophys. Res. 73, 2225-2236.

Darot, M., Gueguen Y., Baratin, M., 1992. Permeability of thermally cracked granite. Geophys. Res. Lett. 19, 869-872.

330 David, C., 1993. Geometry of flow paths for fluid transport in rocks. J. Geophys. Res. 
331

$98,12267-12278$.

Esaki, T., Zhang, M., Takeshita, A., Mitani, Y., 1996. Rigorous theoretical analysis of a flow pump permeability test. Geotech. Test. J. 19, 241-246.

Fortin, J., Stanchits, S., Vinciguerra, S., Guèguen, Y., 2011. Influence of thermal and mechanical cracks on permeability and elastic wave velocities in a basalt from Mt. Etna volcano subjected to elevated pressure. Tectonophysics 503, 60-74.

Francisca, F., Yun, T.S., Ruppel, C., Santamarina, J.C., 2005. Geophysical and geotechnical properties of near-seafloor sediments in the northern Gulf of Mexico gas hydrate province. Earth Planet. Sci. Lett. 237, 924-939.

Fujii, Y., Takemura, T., Takahashi, M., Lin, W., 2007. Surface features of uniaxial tensile fractures and their relation to rock anisotropy in Inada granite. Int. J. Rock Mech. Min. Sci. 44, 98-107.

Griffiths, L., Heap, M.J., Xu, T., Chen, C., Baud, P., 2017. The influence of pore geometry and orientation on the strength and stiffness of porous rock. J. Struct. Geol. 96, 149-160.

Gueguen, Y., Dienes, J., 1989. Transport properties of rocks from statistics and percolation. Math. Geol. 21, 1-13.

Gueguen, Y., Chelidze, T., Le Ravalec, M., 1997. Microstructures, percolation thresholds, and rock physical properties. Tectonophysics 279, 23-35.

Hashiba, K., Fukui, K., 2016. Time-dependent behaviors of granite: Loading-rate dependence, creep, and relaxation. Rock Mech. Rock Eng. 49, 2569-2580.

Hazzard, J.F., Young, R.P., Maxwell, S.C., 2000. Micromechanical modelling of cracking and failure in brittle rocks. J. Geophys. Res. 105, 16683-16697.

Heap, M.J., Baud, P., Reuschlé, T., Meredith, P.G., 2014. Stylolites in limestones: 
Hsieh, P.A., Tracy, J.V., Bredehoeft, J.D., Silliman, S.E., 1981. A transient laboratory method for determining the hydraulic properties of 'tight' rocks-I. theory. Int. J. Rock Mech. Min. Sci. \& Geomech. Abstr. 18, 245-252.

Ishibashi, M., Yoshida, H., Sasao, E., Yuguchi, T., 2016. Long term behavior of hydrogeological structures associated with faulting: An example from the deep crystalline rock in the Mizunami URL, Central Japan. Eng. Geol. 208, 114-127.

Iwatsuki, T., Furue, R., Mie, H., Ioka, S., Mizuno, T., 2005. Hydrochemical baseline condition of groundwater at the Mizunami underground research laboratory (MIU). Appl. Geochem. 20, 2283-2302.

Koike, K., Kubo, T., Liu, C., Masoud, A., Amano, K., Kurihara, A., Matsuoka, T., Lanyon, B., 2015. 3D geostatistical modelling of fracture system in a granitic massif to characterize hydraulic properties and fracture distribution. Tectonophysics 660, 1-16.

Kranz, R.L., Frankel, A.D., Engelder, T., Scholz, C.H., 1979. The permeability of whole and jointed Barre granite. Int. J. Rock Mech. Min. Sci. \& Geomech. Abstr. 16, 225234.

Lanaro, F., Sato, T., Nakama, S., 2009. Depth variability of compressive strength test results of Toki granite from Shobasama and Mizunami construction sites, Japan. Rock Mech. Rock Eng. 42, 611-629.

Morin, R.H., Olsen, H.W., 1987. Theoretical analysis of the transient pressure response from a constant flow rate hydraulic conductivity test. Water Resour. Res. 23, 14611470.

Morrow, C.A., Lockner, D.A., 1997. Permeability and porosity of the Illinois UPH 3 drillhole granite and a comparison with other deep drillhole rocks. J. Geophys. Res. 102, 3067-3075. 
381 Nara, Y., 2015. Effect of anisotropy on the long-term strength of granite. Rock Mech.

382

383

384 Rock Eng. 48, 959-969.

Nara, Y., Kaneko, K., 2006. Sub-critical crack growth in anisotropic rock. Int. J. Rock Mech. Min. Sci. 43, 437-453.

Nara, Y., Meredith, P.G., Yoneda, T., Kaneko, K., 2011a. Influence of macro-fractures and micro-fractures on permeability and elastic wave velocities in basalt at elevated pressure. Tectonophysics 503, 52-59.

Nara, Y., Cho, S.H., Yoshizaki, T., Kaneko, K., Sato, T., Nakama, S., Matsui, H., 2011b. Estimation of three-dimensional stress distribution and elastic moduli in rock mass of the Tono area, International Journal of the Japanese Committee for Rock Mechanics 7, $1-9$.

Nara, Y., Kato, H., Yoneda, T., Kaneko, K., 2011c. Determination of three-dimensional microcrack distribution and principal axes for granite using a polyhedral specimen, Int. J. Rock Mech. Min. Sci. 48, 316-335.

Nara, Y., Morimoto, K., Yoneda, T., Hiroyoshi, N., Kaneko, K., 2011d. Effects of humidity and temperature on subcritical crack growth in sandstone. Int. J. Solids Struct. 48, 1130-1140.

Nara, Y., Morimoto, K., Hiroyoshi, N., Yoneda, T., Kaneko, K., Benson, P.M., 2012. Influence of relative humidity on fracture toughness of rock: implications for subcritical crack growth. Int. J. Solids Struct. 49, 2471-2481.

Nara, Y., Nakabayashi, R., Maruyama, M., Hiroyoshi, N., Yoneda, Y., Kaneko, K., 2014. Influences of electrolyte concentration on subcritical crack growth in sandstone in water. Eng. Geol. 179, 41-49

Nasseri, M.H.B., Mohanty, B., Robin, P.-Y.F., 2005. Characterization of microstructures and fracture toughness in five granitic rocks. Int. J. Rock Mech. Min. Sci. 42, 450- 
$406 \quad 460$.

407 Nasseri, M.H.B., Schubnel, A., Young, R.P., 2007. Coupled evolutions of fracture

408 toughness and elastic wave velocities at high crack density in thermally treated

409 Westerly granite. Int. J. Rock Mech. Min. Sci. 44, 601-616.

410 Nasseri, M.B.H., Schubnel, A., Benson, P.M., Young, R.P., 2009. Common evolution of

411 mechanical and transport properties in thermally cracked Westerly granite at

412 elevated hydrostatic pressure. Pure Appl. Geophys. 166, 927-948.

413 Norton, D., Knapp, R., 1977. Transport phenomena in hydrothermal systems: the nature $414 \quad$ of porosity. Am. J. Sci. 227, 913-936.

415 Olsen, H.W., 1966. Darcy's law in saturated kaolinite. Water Resour. Res. 2, 287-295

416 Oron, A.P., Berkowitz, B., 1998. Flow in rock fractures: the local cubic law assumption $417 \quad$ reexamined. Water Resour. Res. 34, 2811-2825.

418 Pratt, H.R., Swolfs, H.S., Brace, W.F., Black, A.D., Handin, J.W., 1977. Elastic and 419 transport properties of an in situ jointed granite. Int. J. Rock Mech. Min. Sci. \& $420 \quad$ Geomech. Abstr. 14, 35-45.

421 Sanada, H., Hikima, R., Tanno, T., Matsui, H., Sato, T., 2013. Application of differential 422 strain curve analysis to the Toki granite for in situ stress determination at the 423 Mizunami underground research laboratory, Japan. Int. J. Rock Mech. Min. Sci. $424 \quad 59,50-56$.

425 Sausse, J., Jacquot, E., Fritz, B., Leroy, J., Lespinasse, M., 2001. Evolution of crack 426 permeability during fluid-rock interaction. Example of the Brèzouard granite (Vosges, France). Tectonophysics 336, 199-214.

Schubnel, A., Nishizawa, O., Masuda, K., Lei, X.J., Xue, Z., Gueguen, Y., 2003. Velocity measurements and crack density determination during wet triaxial 430 experiments on Oshima and Toki granites. Pure Appl. Geophys. 160, 869-887. 
431 Suzuki, K., Oda, M., Yamazaki, M., Kuwahara, T., 1998. Permeability change in granite 432 with crack growth during immersion in hot water. Int. J. Rock Mech. Min. Sci. 35, 907-921.

Unger, A. J. A., Mase, C.W., 1993. Numerical study of the hydromechanical behavior of two rough fracture surfaces in contact. Water Resour. Res. 29, 2101-2114.

Vinciguerra, S., Trovato, C., Meredith, P.G., Benson, P.M., 2005. Relating seismic velocities, thermal cracking and permeability in Mt. Etna and Iceland basalts. Int. J. Rock Mech. Min. Sci. 42, 900-910.

Walsh, J.B., 1965. The effect of cracks on the compressibility of rock. J. Geophys. Res. 70, 381-389.

Walsh, J.B., 1981. Effect of pore pressure and confining pressure on fracture permeability. Int. J. Rock Mech. Min. Sci. \& Geomech. Abstr. 18, 429-435.

Wang, G., Mitchell, T.M., Meredith, P.G., Nara, Y., Wu, Z., 2016. Influence of gouge thickness on permeability of macro-fractured basalt. J. Geophys. Res. 121, 8472-8487.

Witherspoon, P.A., Wang, J.S.Y., Iwai, K., Gale, J.E., 1980. Validity of cubic law for fluid flow in a deformable rock failure. Water Resour. Res. 16, 1016-1024.

Yamamoto, K., Yoshida, H., Akagawa, F., Nishimoto, S., Metcalfe, R., 2013. Redox front penetration in the fractured Toki granite, central Japan: An analogue for redox reactions and redox buffering in fractured crystalline host rocks for repositories of long-lived radioactive waste. Appl. Geochem. 35, 75-87.

Yamasaki, S., Zwingmann, H., Yamada, K., Tagami, T., Umeda, K., 2013. Constraining the timing of brittle deformation and faulting in the Toki granite, central Japan. Chem. Geol. 351, 168-174.

Yuguchi, T., Tagami, M., Tsuruta, T., Nishiyama, T., 2012. Three-dimensional fracture distribution in relation to local cooling in a granitic body: An example from the Toki 
1

456 granitic pluton, Central Japan. Eng. Geol. 149-150, 35-46.

457 Zhang, M., Takahashi, M., Morin, R.H., Esaki, T., 2000. Evaluation and application of the 458 transient-pulse technique for determining the hydraulic properties of low-permeability 459 rocks - Part 1: theoretical evaluation. Geotech. Test. J. 23, 83-90.

460 Zhang, M., Takahashi, M., Morin, R.H., Esaki, T., 2000. Evaluation and application of the 461 transient-pulse technique for determining the hydraulic properties of low-permeability 462 rocks - Part 2: experimental application. Geotech. Test. J. 23, 91-99. 
463 Table

464

465 Table 1 Summary of the hydraulic conductivity for Toki granite at elevated pressures

\begin{tabular}{|c|c|c|}
\hline & $\begin{array}{l}\text { Effective confining pressure } \\
\qquad[\mathrm{MPa}]\end{array}$ & $\begin{array}{l}\text { Hydraulic conductivity } \\
\qquad[\mathrm{m} / \mathrm{s}]\end{array}$ \\
\hline \multirow{9}{*}{$\begin{array}{l}\text { Intact specimen } \\
\qquad(\mathrm{TG}-\mathrm{i})\end{array}$} & 1.07 & $3.75 \times 10^{-12} \pm 1.79 \times 10^{-14}$ \\
\hline & 1.98 & $4.66 \times 10^{-12} \pm 6.89 \times 10^{-14}$ \\
\hline & 3.05 & $3.98 \times 10^{-12} \pm 6.90 \times 10^{-14}$ \\
\hline & 4.04 & $2.97 \times 10^{-12} \pm 1.64 \times 10^{-14}$ \\
\hline & 5.04 & $2.78 \times 10^{-12} \pm 2.38 \times 10^{-14}$ \\
\hline & 5.96 & $2.62 \times 10^{-12} \pm 2.72 \times 10^{-14}$ \\
\hline & 7.00 & $2.27 \times 10^{-12} \pm 4.72 \times 10^{-14}$ \\
\hline & 8.02 & $3.34 \times 10^{-12} \pm 3.27 \times 10^{-14}$ \\
\hline & 9.01 & $4.62 \times 10^{-12} \pm 3.39 \times 10^{-14}$ \\
\hline \multirow{6}{*}{$\begin{array}{l}\text { Macro-fractured specimen } \\
\text { without filling } \\
\text { (TG-f) }\end{array}$} & 0.95 & $5.56 \times 10^{-8} \pm 2.54 \times 10^{-9}$ \\
\hline & 2.97 & $1.71 \times 10^{-8} \pm 5.28 \times 10^{-10}$ \\
\hline & 3.78 & $1.03 \times 10^{-8} \pm 4.25 \times 10^{-10}$ \\
\hline & 4.94 & $7.09 \times 10^{-9} \pm 2.35 \times 10^{-10}$ \\
\hline & 6.87 & $2.87 \times 10^{-9} \pm 9.90 \times 10^{-10}$ \\
\hline & 8.94 & $3.62 \times 10^{-9} \pm 9.20 \times 10^{-10}$ \\
\hline \multirow{7}{*}{$\begin{array}{l}\text { Specimen with a mineral vein } \\
\text { (TG-v) }\end{array}$} & 1.22 & $8.63 \times 10^{-12} \pm 1.56 \times 10^{-13}$ \\
\hline & 1.97 & $6.42 \times 10^{-12} \pm 7.34 \times 10^{-14}$ \\
\hline & 2.83 & $5.65 \times 10^{-12} \pm 1.06 \times 10^{-13}$ \\
\hline & 3.84 & $6.70 \times 10^{-12} \pm 3.65 \times 10^{-14}$ \\
\hline & 4.84 & $5.90 \times 10^{-12} \pm 9.86 \times 10^{-14}$ \\
\hline & 6.69 & $4.76 \times 10^{-12} \pm 6.52 \times 10^{-14}$ \\
\hline & 8.89 & $4.33 \times 10^{-12} \pm 4.48 \times 10^{-14}$ \\
\hline \multirow{7}{*}{$\begin{array}{l}\text { Specimen with a macro-fracture } \\
\text { filled with clay } \\
\text { (TG-c) }\end{array}$} & 0.97 & $7.59 \times 10^{-11} \pm 2.13 \times 10^{-12}$ \\
\hline & 2.02 & $4.43 \times 10^{-11} \pm 1.01 \times 10^{-12}$ \\
\hline & 3.03 & $3.21 \times 10^{-11} \pm 4.96 \times 10^{-13}$ \\
\hline & 4.08 & $1.98 \times 10^{-11} \pm 3.70 \times 10^{-13}$ \\
\hline & 5.03 & $1.67 \times 10^{-11} \pm 1.64 \times 10^{-13}$ \\
\hline & 7.01 & $1.25 \times 10^{-11} \pm 5.16 \times 10^{-14}$ \\
\hline & 9.03 & $1.06 \times 10^{-11} \pm 4.94 \times 10^{-14}$ \\
\hline
\end{tabular}




\section{$467 \quad$ Figure caption}

468 Fig. 1 Photos of Toki granite. (a): Rock core sample (65-mm diameter) with a macrocore sample (65-mm diameter) with clay filling.

Fig. 2 Photos of (a) the intact specimen (TG-i), (b) macro-fractured specimen (TG-f), (c) specimen with a vein of fine-grained minerals (TG-v), and (d) specimen with a macro-fracture filled with clay (TG-c). Diameter and length of the specimens are 50 and $25 \mathrm{~mm}$, respectively.

Fig. 3 Photomicrographs of (a) the intact specimen (TG-i), (b) specimen with a vein of fine-grained minerals (TG-v), and (c) specimen with a macro-fracture filled with clay (TG-c). Length and height of the photomicrographs are 1.95 and $1.25 \mathrm{~mm}$, respectively.

Fig. 4 Schematic of the permeability measurement system.

Fig. 5 Temporal changes of the upstream and downstream hydraulic pressure difference for (a) the intact specimen (TG-i), (b) specimen with a vein of finegrained minerals (TG-v), and (c) specimen with a macro-fracture filled with clay (TG-c) at a confining pressure of $2 \mathrm{MPa}$ obtained by the transient pulse method. The accuracy of the upstream and downstream hydraulic pressure difference was $0.35 \mathrm{kPa}$.

Fig. 6 Temporal change of the upstream and downstream hydraulic pressure difference in the macro-fractured specimen (TG-f) at a confining pressure of $2 \mathrm{MPa}$ obtained by the constant flow method. The accuracy of the upstream and downstream hydraulic pressure difference was $0.35 \mathrm{kPa}$.

Fig. 7 Relationships between permeability and effective confining pressure for an intact sample, a macro-fractured sample, a sample containing a mineral vein, and a 
1

492 sample containing a macro-fracture filled with clays of Toki granite.

493 Fig. 8 Relationships between hydraulic aperture of equivalent fracture and effective $494 \quad$ confining pressure for Toki granite.

495

496

497 The English in this document has been checked by native speakers of English, from an 498 English editing service company:

$499 \quad$ https://www.zenis.co.jp/eng/index.html

500 
Click here to download Figure Figure_1a(macro_fracture).jpg $\stackrel{ \pm}{*}$

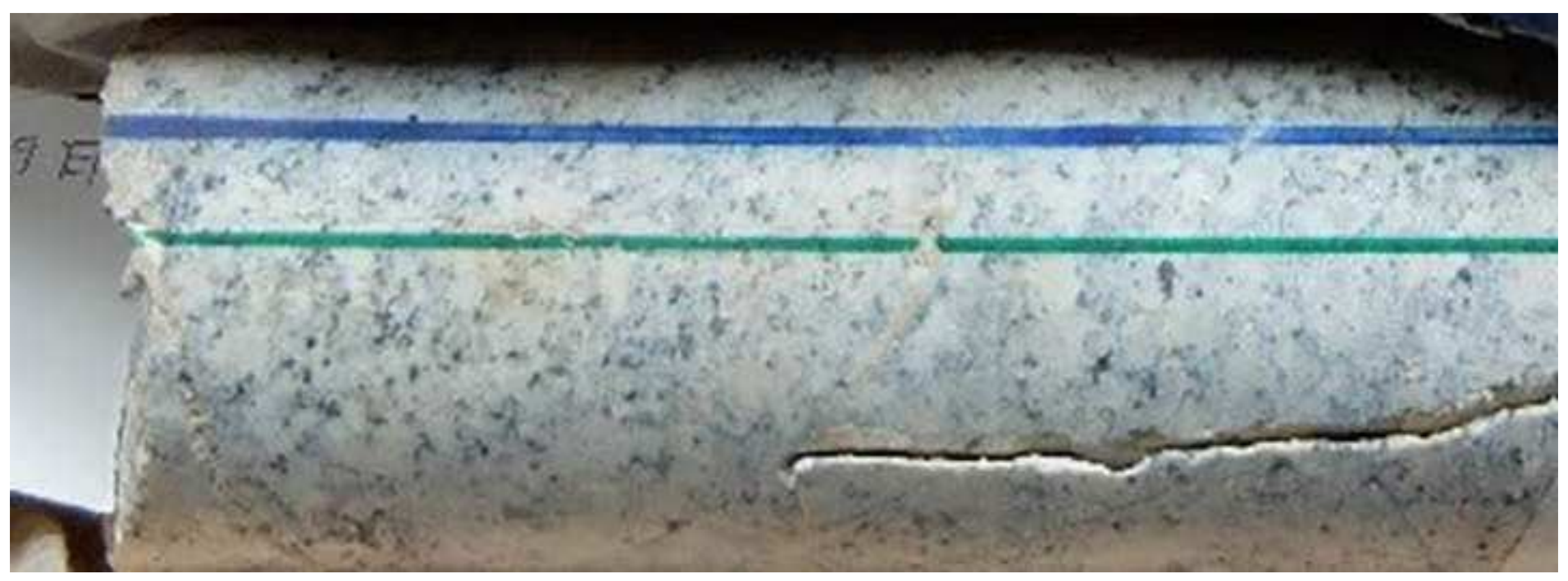


Figure1b Click here to download Figure Figure_1b(core_vein).jpg $\underline{\underline{\boldsymbol{*}}}$
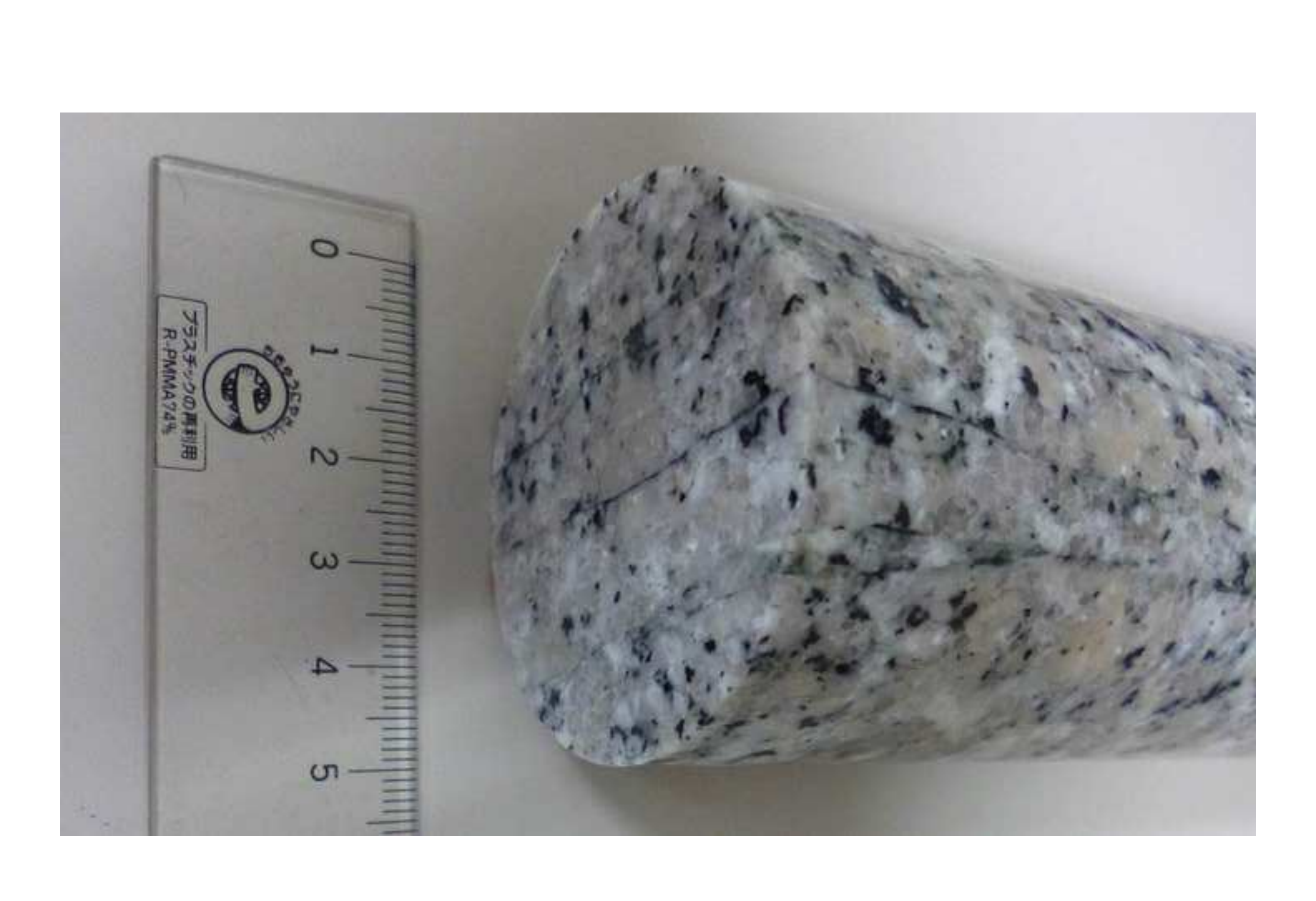

(1) 
Click here to download Figure Figure_1c(core_clay).jpg $\underline{\underline{ }}$
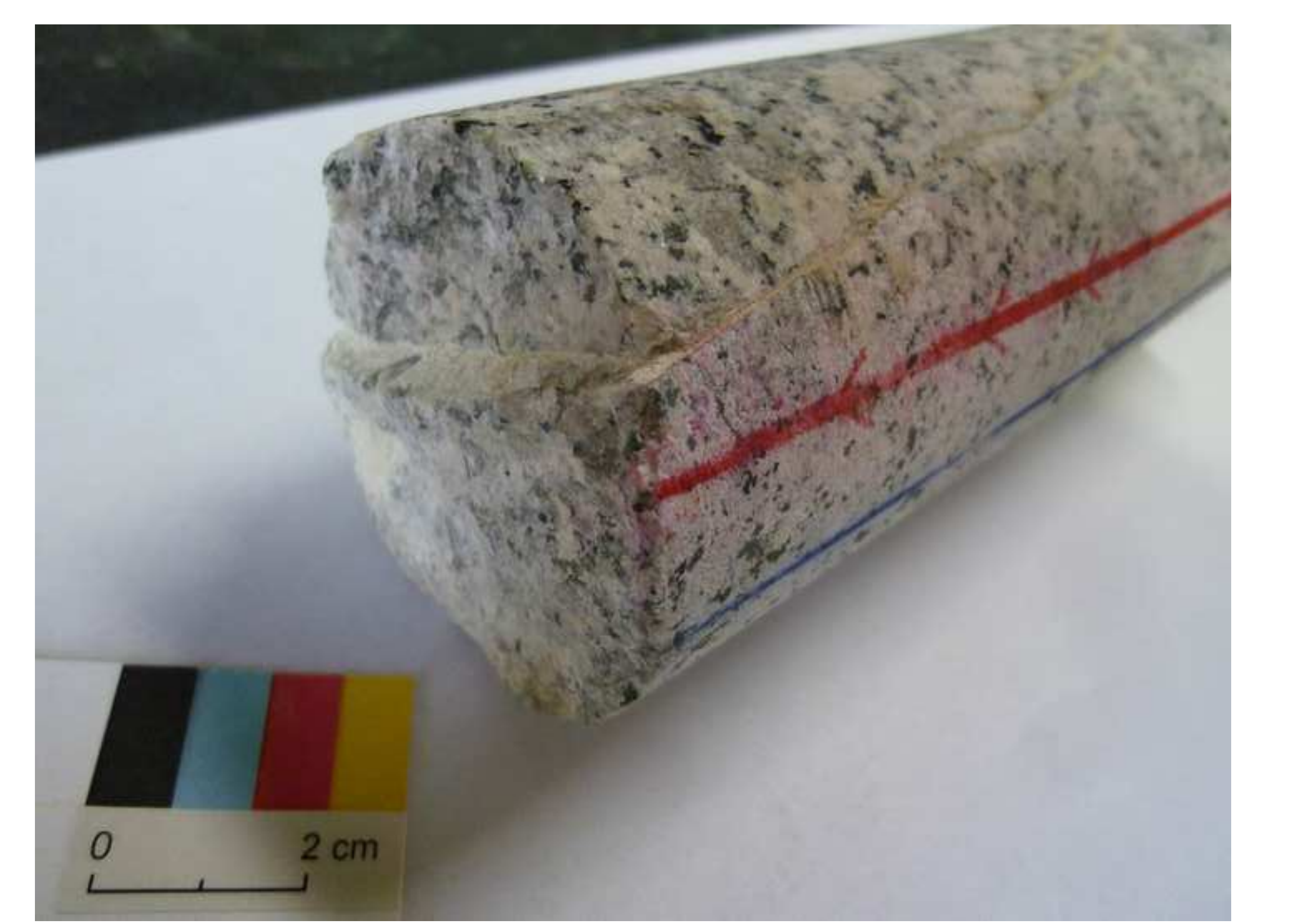
Click here to download Figure Figure_2b(TG-f).jpg $\underline{\underline{ \pm}}$

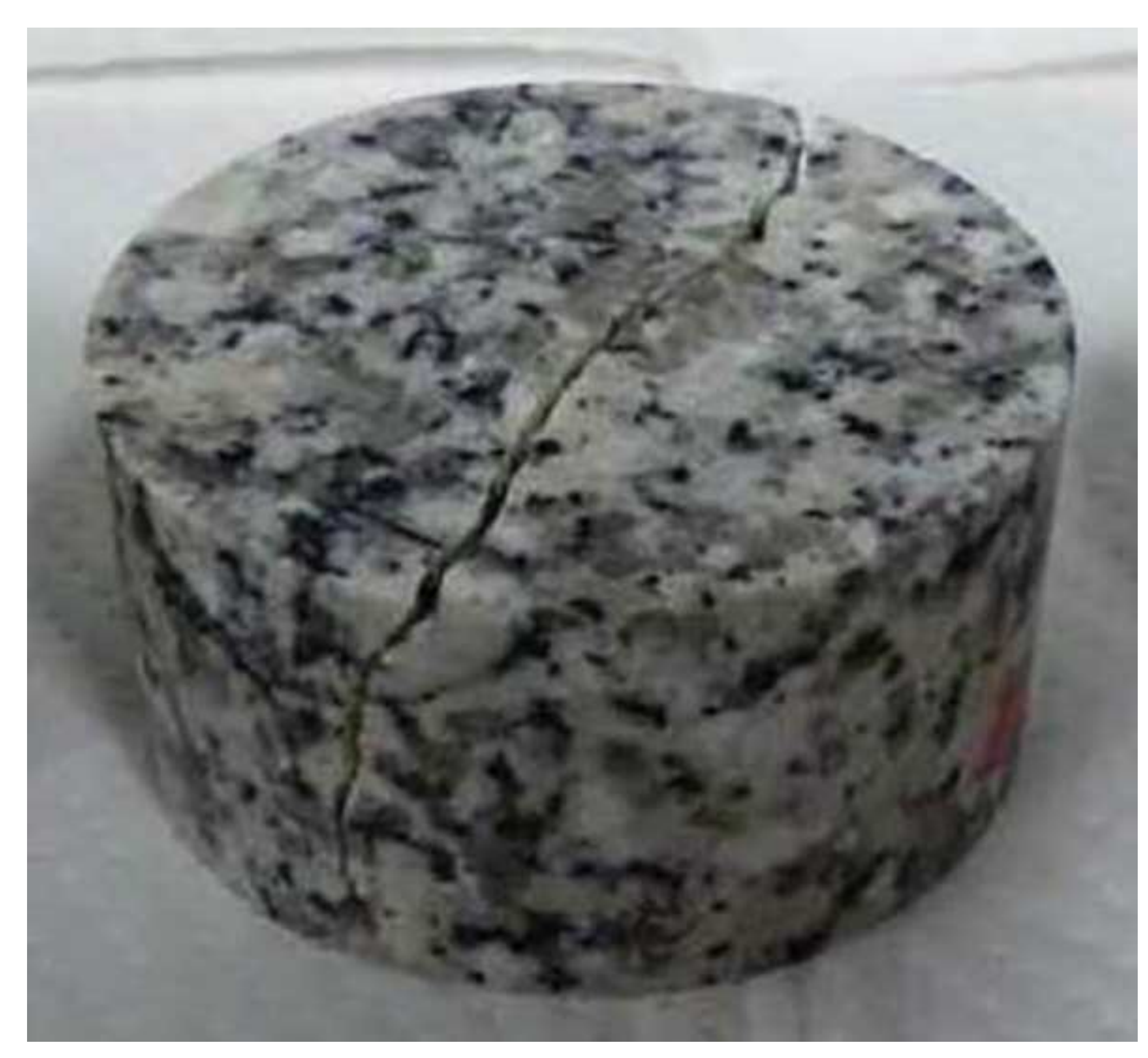
.

\author{
.
}
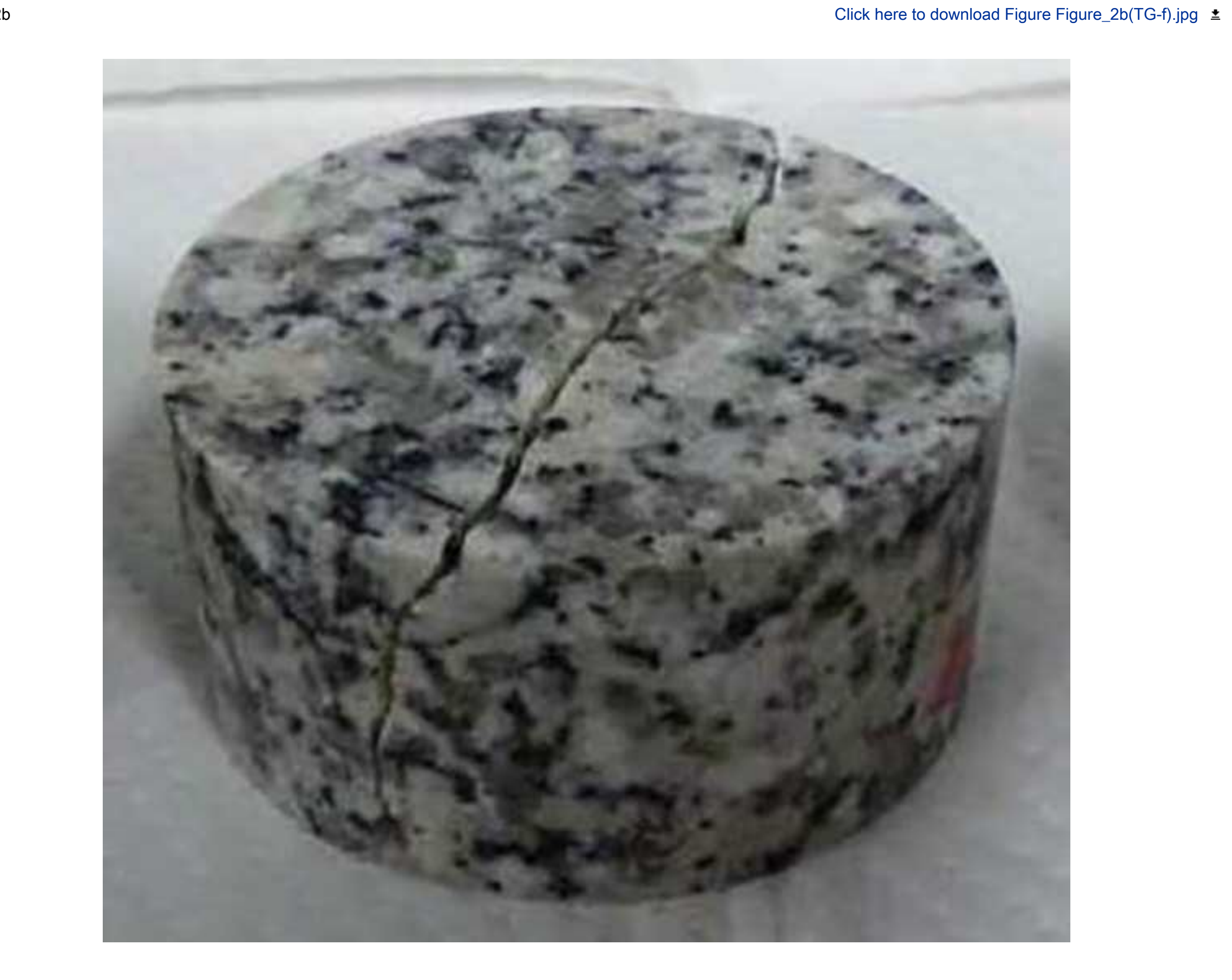


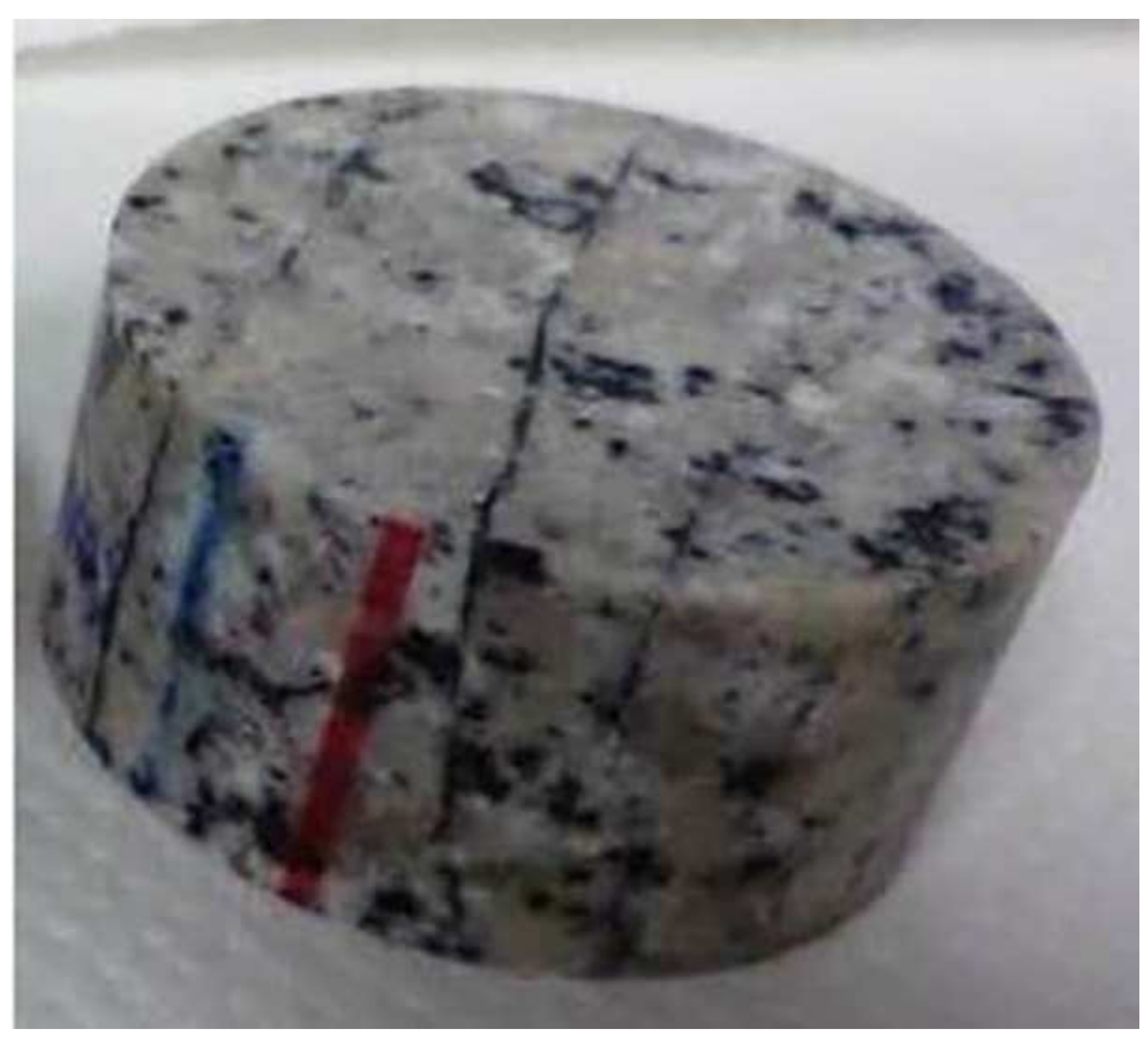

\section{.
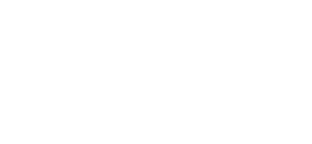

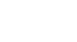

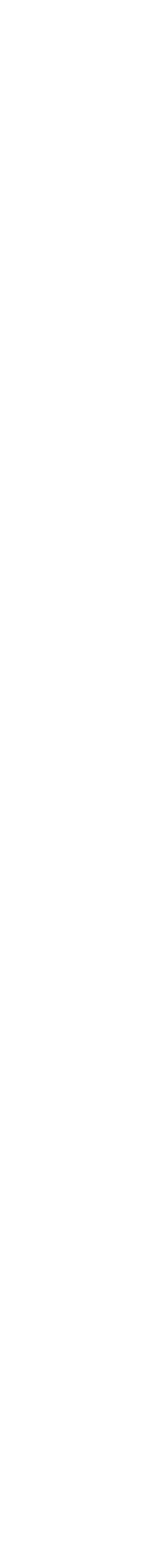

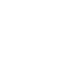
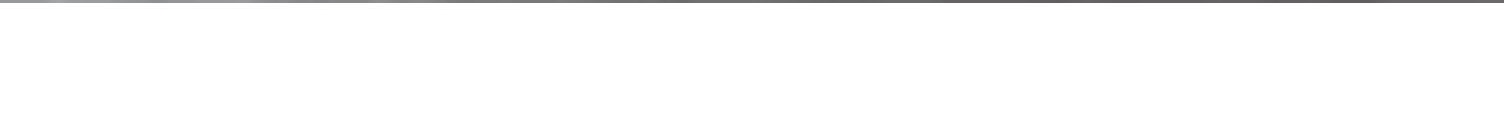

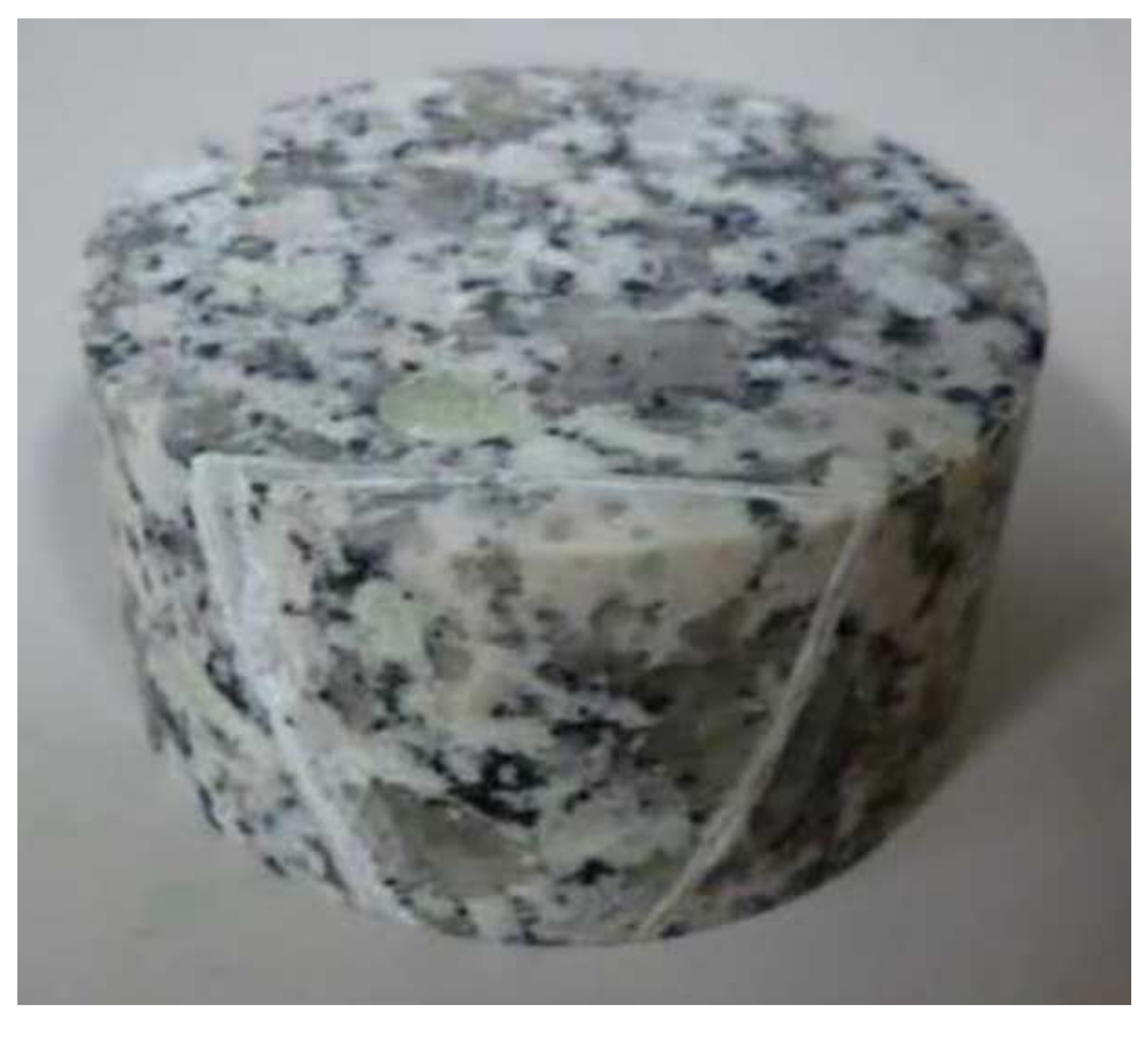

.

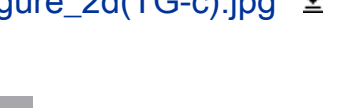




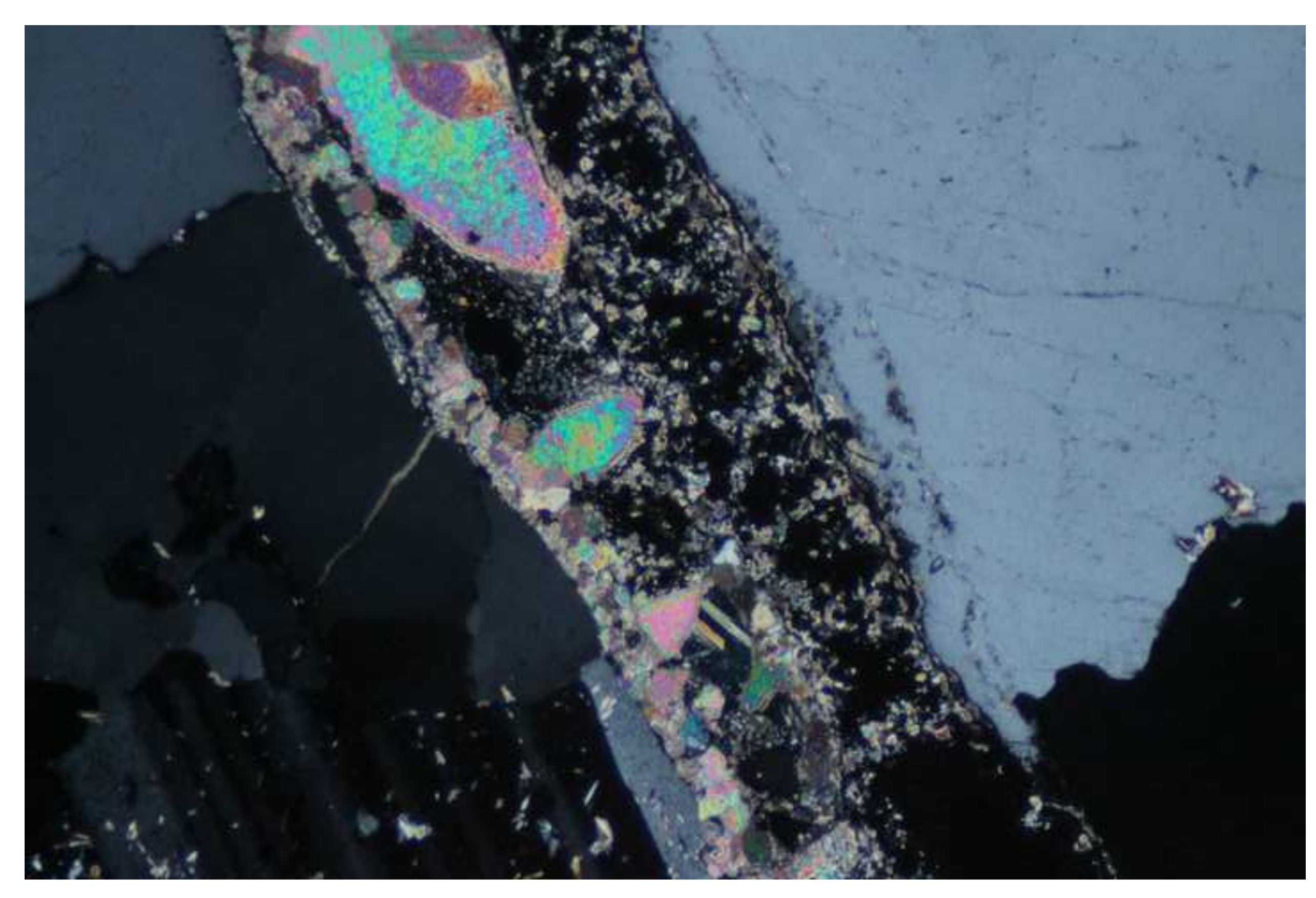




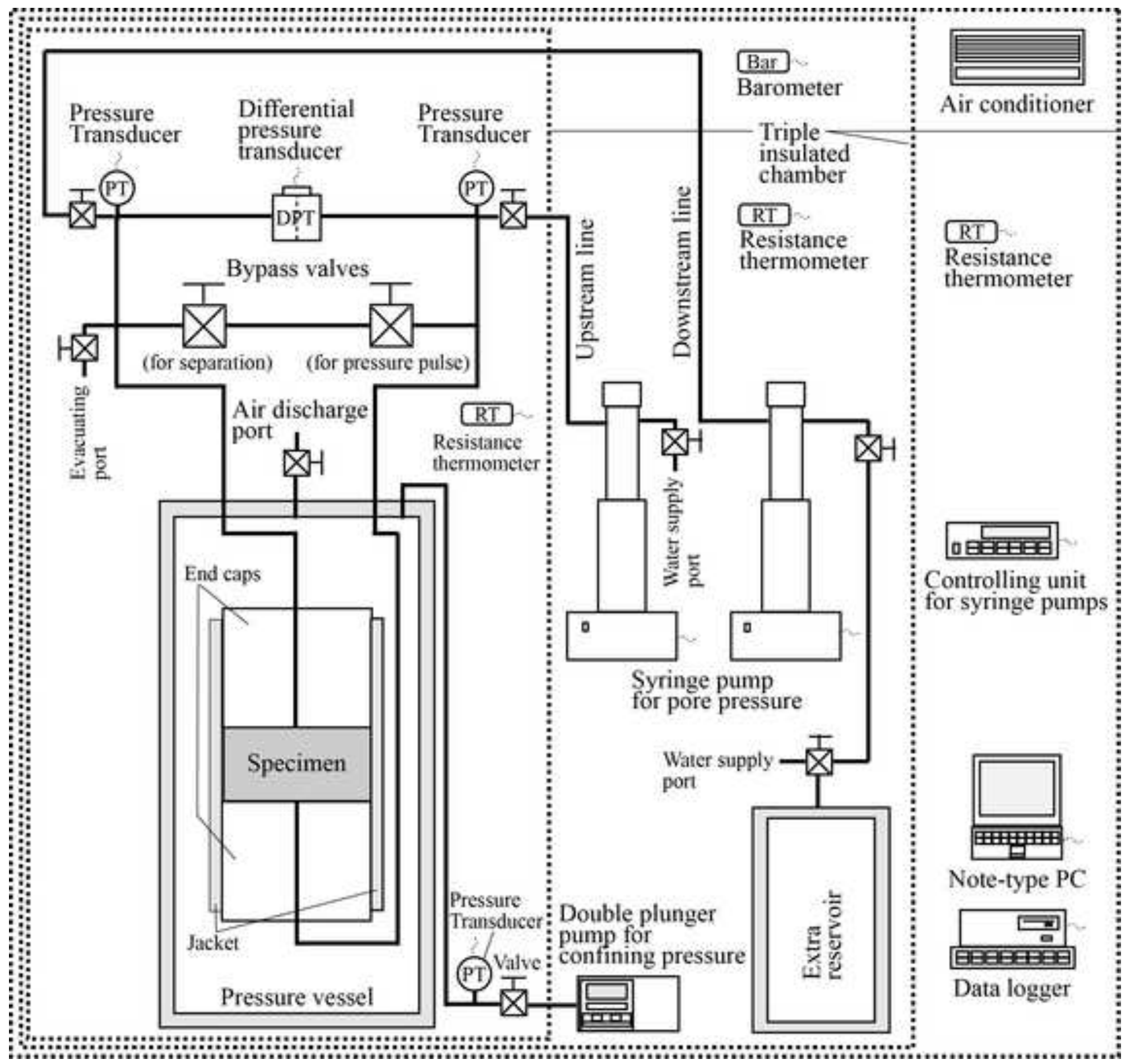




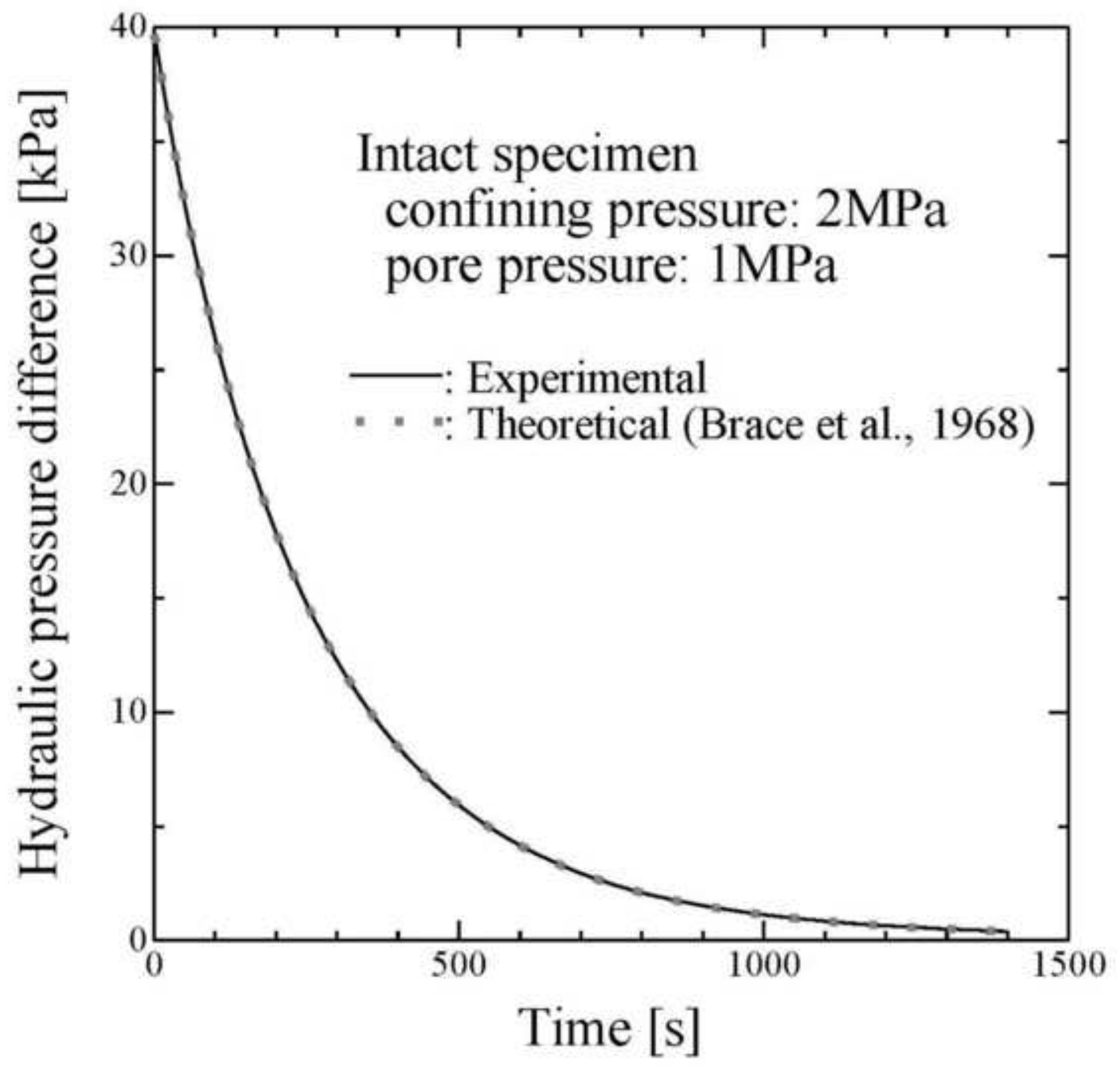




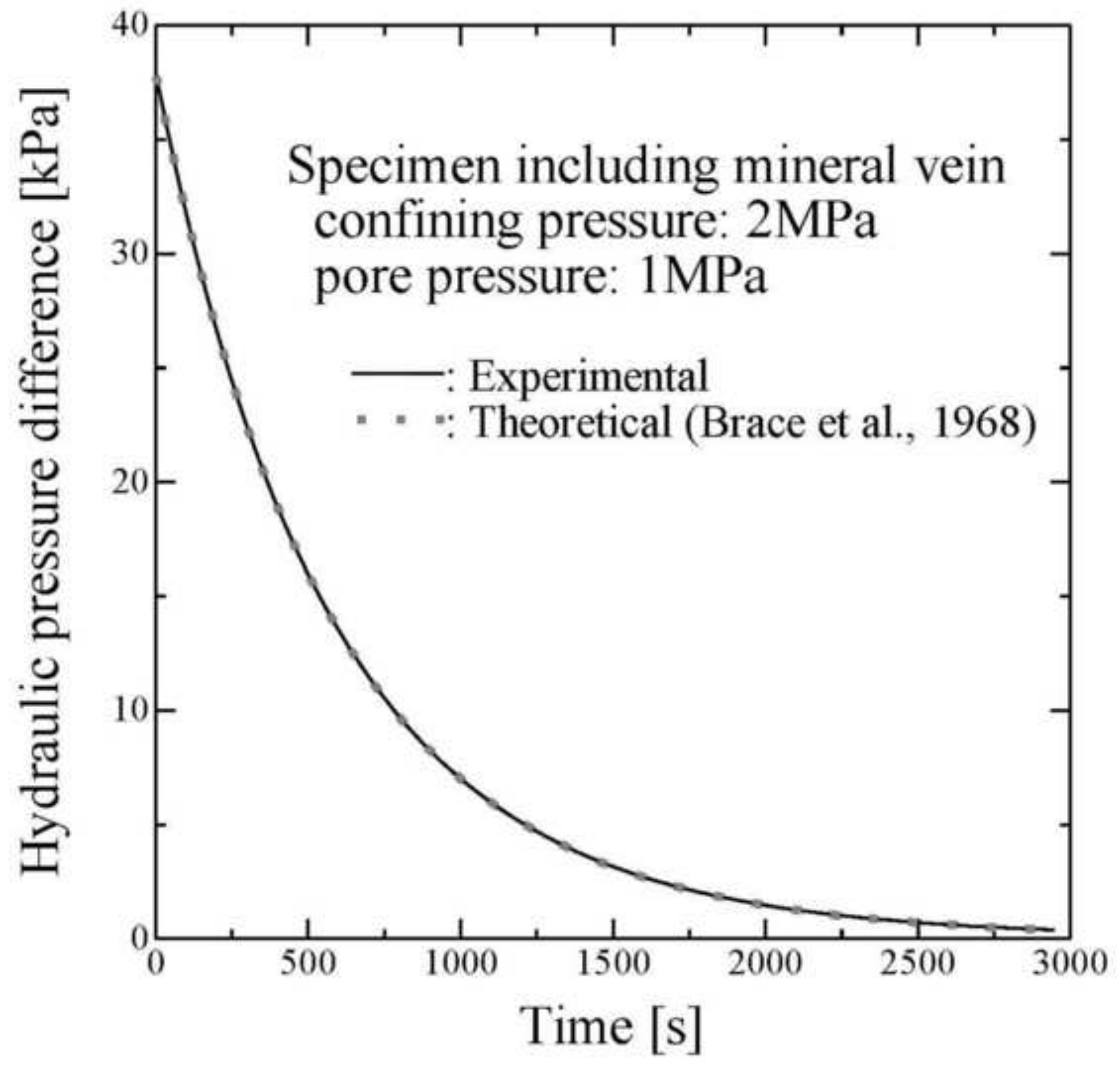




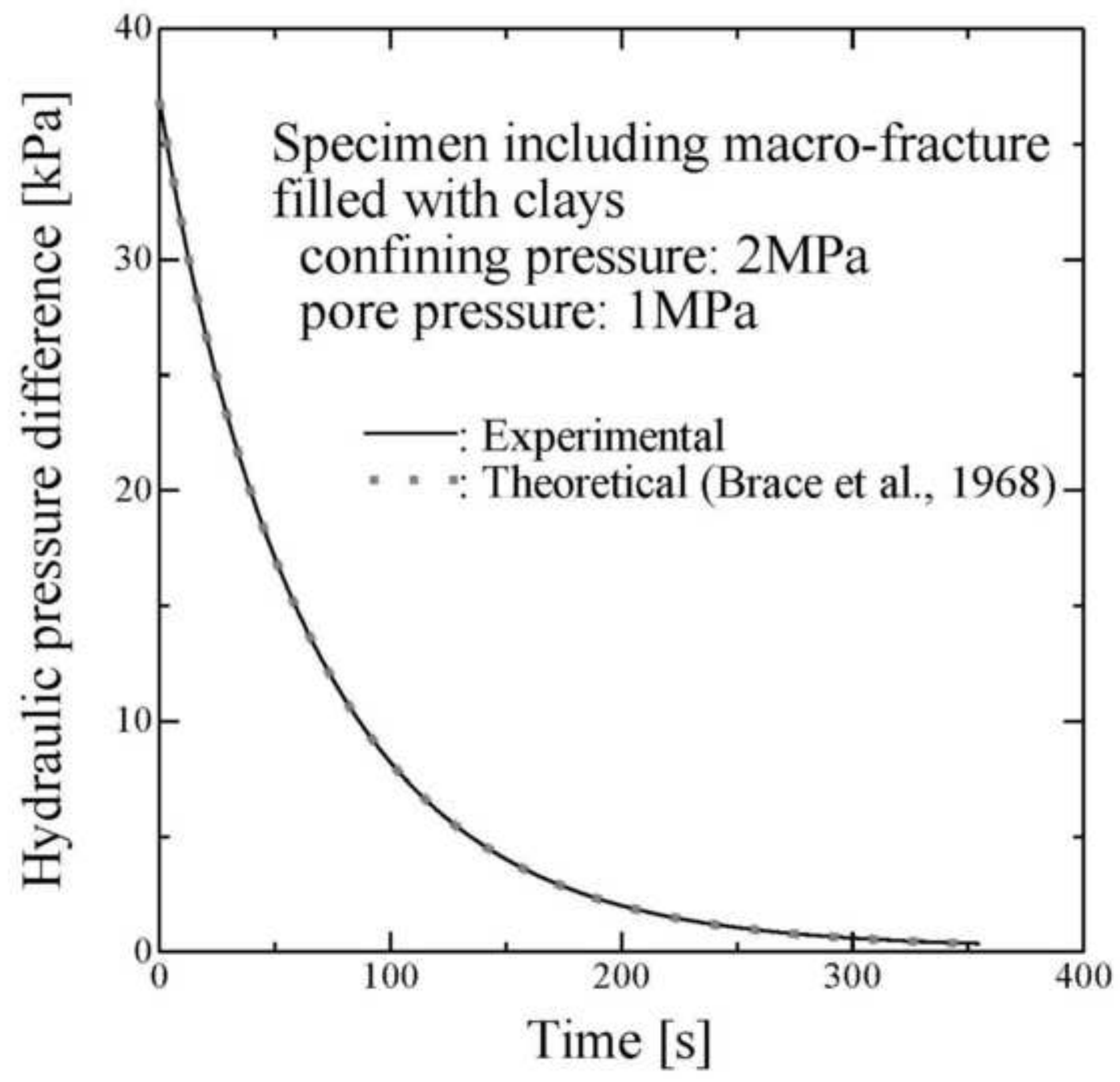




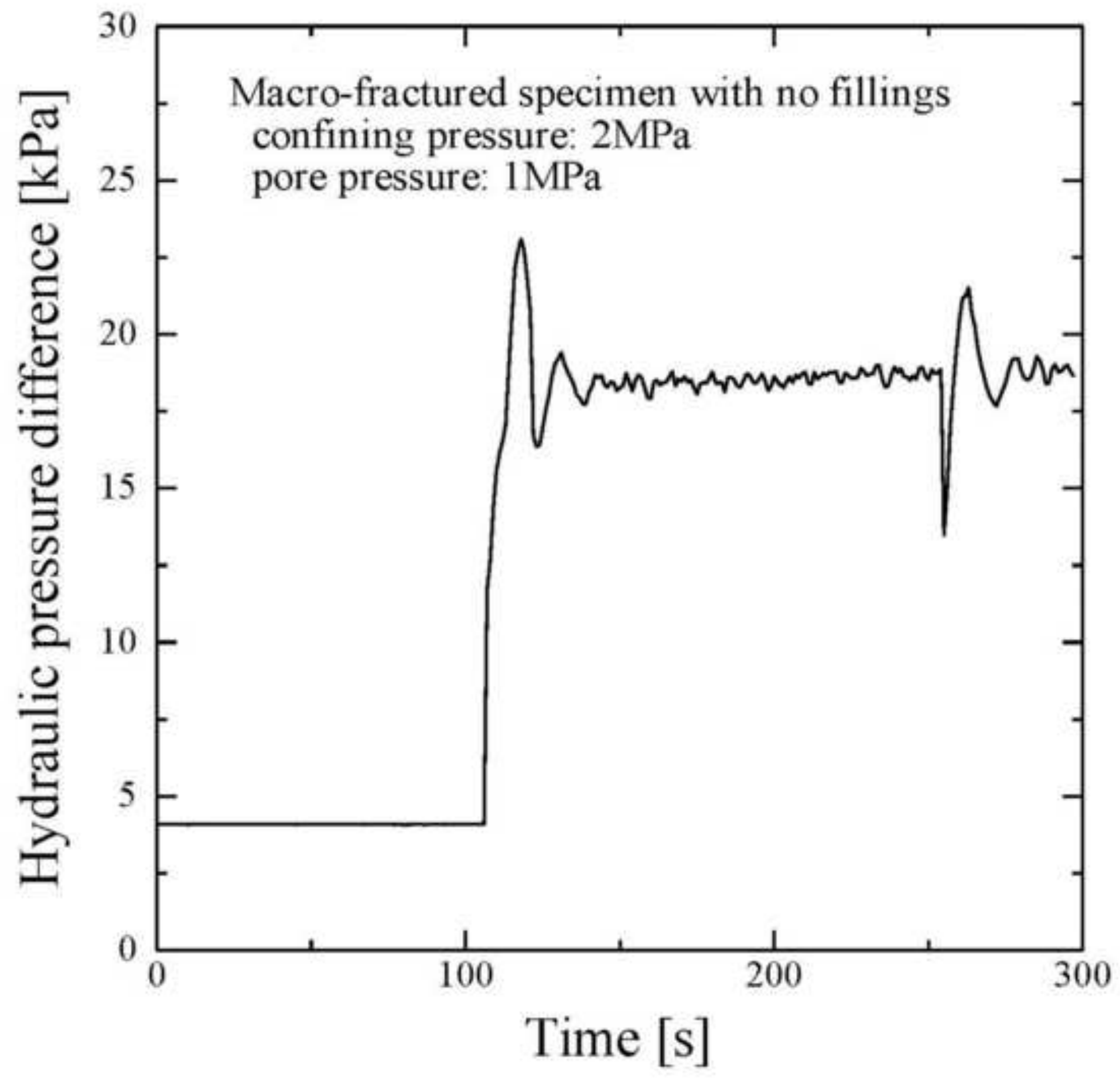




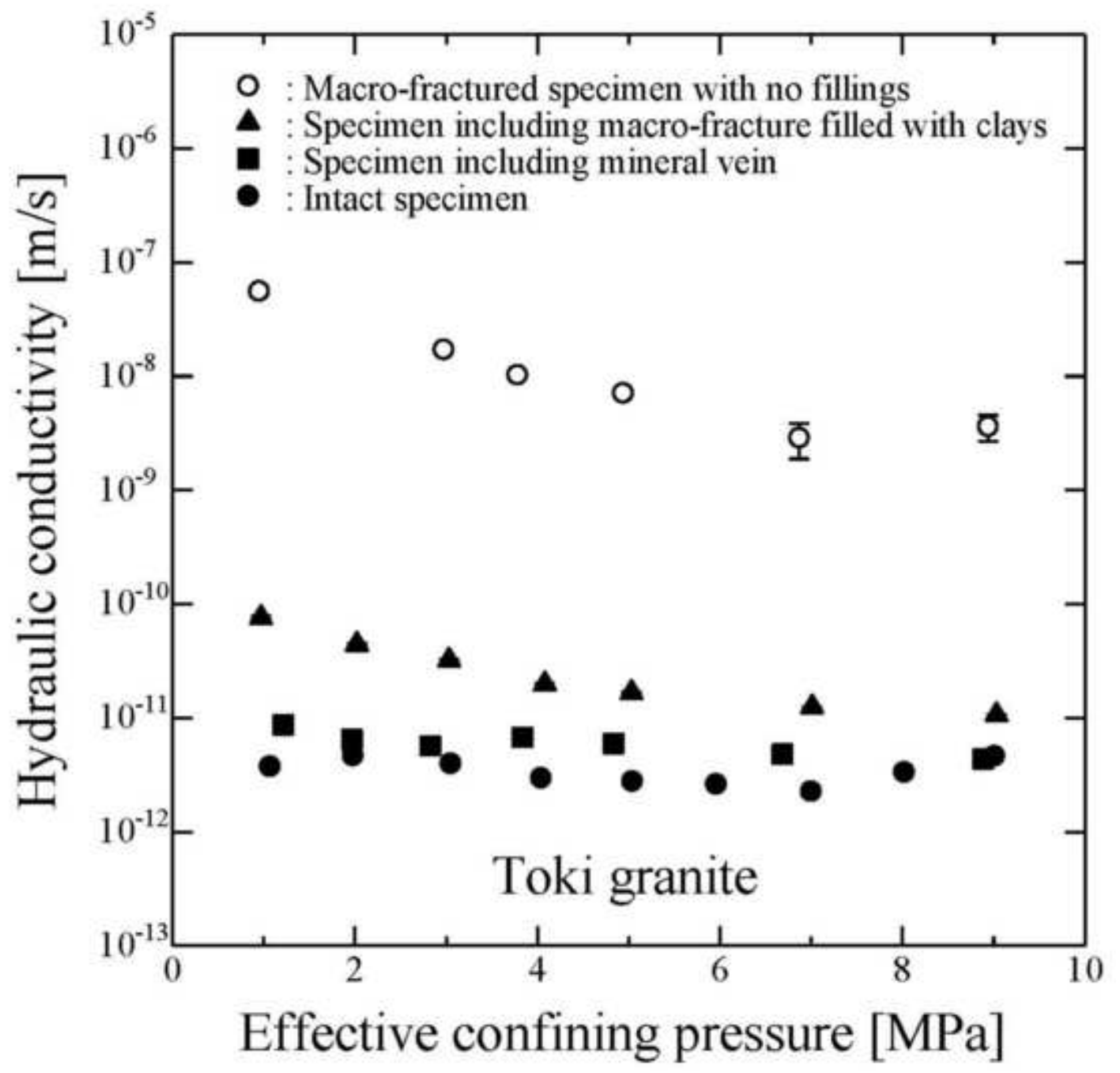




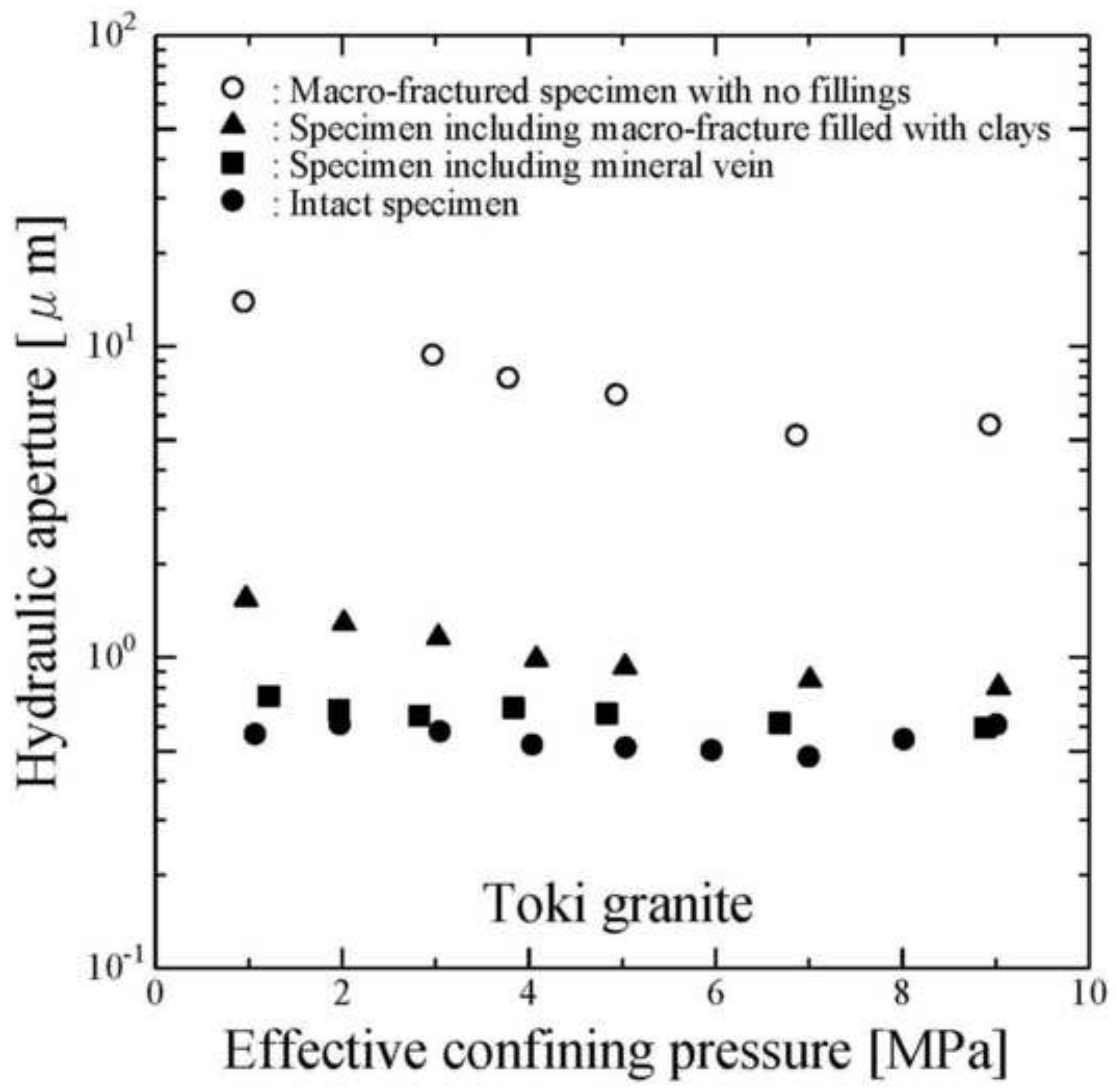

